\title{
De beslispraktijk van het Schadefonds Geweldsmisdrijven: een kwalitatieve studie naar de beoordeling van verzoeken tot tegemoetkoming
}

\author{
Mara Huibers, Maarten Kunst \& Sigrid van Wingerden
}

\section{$1 \quad$ Inleiding}

Jaarlijks wordt zo'n $2 \%$ van de Nederlandse bevolking het slachtoffer van een ernstig geweldsmisdrijf (Centraal Bureau voor de Statistiek 2016). De impact die zo'n misdrijf heeft op het slachtoffer is vaak groot, zeker wanneer het gaat om zeer ernstige vormen van geweld, zoals verkrachting of zware lichamelijke mishandeling. Het slachtoffer loopt dan een aanzienlijk risico op het ontwikkelen van een posttraumatische stressstoornis en langdurig ziekteverzuim (Kunst 2010; Macmillan 2001). De kosten die met deze gevolgen gepaard gaan, kunnen niet altijd op de dader verhaald worden en komen lang niet altijd voor vergoeding door verzekeraars in aanmerking. Om te voorkomen dat slachtoffers hierdoor in de financiële problemen geraken en als blijk van solidariteit, is in 1975 het Schadefonds Geweldsmisdrijven (hierna: het schadefonds) opgericht (Cozijn 1984). Sindsdien kunnen slachtoffers die ten gevolge van een in Nederland opzettelijk gepleegd geweldsmisdrijf ernstig lichamelijk of geestelijk letsel hebben opgelopen in aanmerking komen voor een financiële tegemoetkoming uit dit fonds, indien en voor zover zij niet via een andere weg schadevergoeding kunnen krijgen. Ook nabestaanden kunnen recht hebben op een tegemoetkoming, maar alleen wanneer het slachtoffer ten gevolge van het misdrijf is overleden. ${ }^{1}$ Jaarlijks dienen circa 7.000 slachtoffers en nabestaanden een aanvraag in voor een financiële tegemoetkoming bij het schadefonds. In zo'n $70 \%$ van de gevallen wordt deze toegekend. $^{2}$

\subsection{De beoordeling van een verzoek tot tegemoetkoming in schade}

Op verzoeken tot tegemoetkoming in geleden schade wordt beslist door de Commissie Schadefonds Geweldsmisdrijven (hierna: commissie SGM). ${ }^{3}$ Deze commissie bestaat uit tien onafhankelijke, door het Ministerie van Justitie en Veiligheid benoemde leden. ${ }^{4}$ De leden zijn zowel juristen als professionals die niet juridisch zijn geschoold, zoals artsen en psychologen. Wat het nemen van primaire beslissingen betreft, heeft de commissie haar beslisbevoegdheid gemanda-

1 Een en ander is geregeld in art. 3 en 6 van de Wet Schadefonds Geweldsmisdrijven.

2 Dit blijkt uit de jaarverslagen. Deze kunnen worden geraadpleegd via www.schadefonds.nl/ jaarverslagen.

3 Dit is bepaald in art. 8 van de Wet Schadefonds Geweldsmisdrijven.

4 Zie www.schadefonds.nl/veelgestelde-vragen/commissieleden-van-het-schadefonds. 
teerd aan de ongeveer vijftig juristen die in dienst zijn bij het Secretariaat Schadefonds Geweldsmisdrijven (hierna: secretariaat SGM). Dat geldt niet voor beslissingen op bezwaar. ${ }^{5}$ Die neemt de commissie SGM zelf. ${ }^{6}$

Bij de beoordeling van een verzoek tot tegemoetkoming in schade hoeft niet, zoals in het strafrecht, wettig en overtuigend bewezen te worden dat het misdrijf heeft plaatsgevonden. Omdat een uitkering uit het schadefonds moet worden gezien als een maatschappelijke blijk van solidariteit met slachtoffers die hun schade niet via andere wegen vergoed kunnen krijgen, wordt een lagere bewijsdrempel gehanteerd. Dit heeft de commissie SGM bepaald in paragraaf 1.1.2 van de Beleidsbundel Schadefonds Geweldsmisdrijven. ${ }^{7}$ Voldoende voor toekenning van een uitkering uit het schadefonds is dat het geweldsmisdrijf 'aannemelijk' is geworden. De beleidsbundel bepaalt dat aan de hand van twee criteria moet worden beoordeeld of aannemelijk is dat de aanvrager het slachtoffer is geworden van een geweldsmisdrijf. In de eerste plaats moet voldoende duidelijk zijn waaruit de feitelijke geweldshandeling bestond. Is bijvoorbeeld een klap uitgedeeld aan de aanvrager of is deze beschoten met een vuurwapen? In de tweede plaats moet voldoende duidelijk zijn wat de aanleiding en toedracht van het misdrijf waren en onder welke omstandigheden het misdrijf heeft plaatsgevonden, omdat een uitkering achterwege kan blijven of op een lager bedrag kan worden vastgesteld, als de toegebrachte schade mede een gevolg is van een omstandigheid die aan het slachtoffer is toe te rekenen. Om te bepalen of aan deze criteria is voldaan, kunnen verschillende bronnen van informatie worden gebruikt. Een belangrijke bron van informatie vormt het proces-verbaal van aangifte. Indien er geen aangifte van het misdrijf is gedaan door het slachtoffer of de aanvraag is gedaan door de nabestaande van een ten gevolge van het misdrijf overleden slachtoffer, kan echter ook andere 'objectieve' informatie worden gebruikt. Hierbij kan onder meer worden gedacht aan rechterlijke uitspraken en informatie die afkomstig is uit openbare bronnen (bijvoorbeeld nieuwsberichten). In uitzonderlijke gevallen kan ook op basis van medische informatie worden bepaald of aan de aannemelijkheidscriteria is voldaan. ${ }^{8}$

\subsection{Probleemstelling}

De juristen van het secretariaat SGM en de leden van de commissie SGM hebben de taak om binnen de beleidskaders van het SGM te beslissen of aan een slachtoffer een financiële tegemoetkoming wordt toegekend. Dit is een complexe taak, die niet volledig in regels en richtlijnen kan worden vastgelegd en een beroep doet op hun sociale vaardigheden; achter iedere aanvraag zit immers het verhaal van een slachtoffer. De beleidsbundel biedt de juristen van het secretariaat SGM en de leden van de commissie SGM enige handvatten om deze taak naar behoren te vervullen (voor voorbeelden, zie vorige paragraaf), maar kent hun tevens veel discre-

5 Zie ook art. 9 van het Besluit Schadefonds Geweldsmisdrijven.

6 Jaarlijks behandelt het schadefonds tussen de vijfhonderd en zeshonderd bezwaarschriften.

7 De meest recente versie van de beleidsbundel kan worden gedownload via www.schadefonds.nl/ wp-content/uploads/Beleidsbundel-20190101.pdf.

$8 \quad$ Zie par. 1.1.2 van de Beleidsbundel. 
tionaire ruimte toe. In deze studie onderzoeken wij hoe zij hier in de praktijk mee omgaan. Dit is belangrijk voor de verdere formalisering van het beleid zoals dat in de beleidsbundel is opgenomen. De resultaten van het onderzoek kunnen namelijk inzicht geven in de persoonlijke beslispraktijken die individuele juristen van het secretariaat SGM en commissieleden erop na houden. Dit inzicht kan de commissie SGM gebruiken om gewenste beslispraktijken vast te leggen in de beleidsbundel en ongewenste beslispraktijken aan te pakken.

\subsection{Theoretisch kader}

Omdat de juristen van het secretariaat SGM en de leden van de commissie SGM bij het nemen van beslissingen over tegemoetkomingen een zekere mate van discretionaire ruimte hebben, wordt in deze studie aangesloten bij de street-level bureaucracy-theorie van Michael Lipsky (1980, 2010). De theorie van Lipsky wordt hiermee toegepast op een beleidsterrein waar deze nog niet eerder is gebruikt.

Volgens Lipsky $(1980,2010)$ zijn street-level bureaucrats professionals die werkzaam zijn in de publieke sector, zoals politieagenten, leraren en rechters. Tijdens de uitoefening van hun dagelijkse werkzaamheden moeten street-level bureaucrats zich houden aan interne regels en hiërarchische structuren en hebben zij veelvuldig persoonlijk contact met burgers die zich - vaak niet geheel vrijwillig - wenden tot de organisatie waarvoor zij werkzaam zijn. Ten aanzien van deze burgers moeten zij beslissingen nemen over het verlenen van bepaalde diensten of rechten. $\mathrm{Zij}$ moeten zich hierbij houden aan bepaalde (wettelijke) regels en beleid dat voorschrijft hoe met deze regels moet worden omgegaan. Tegelijkertijd biedt met name het beleid ook ruimte voor eigen invulling en interpretatie van de regels. Street-level bureaucrats zijn daarom misschien wel de 'ultimate policy makers' (Bosma et al. 2016).

Bovengenoemde kenmerken maken het werk van de street-level bureaucrat paradoxaal: enerzijds moeten zij zich houden aan bepaalde formaliteiten, terwijl anderzijds van hen verwacht wordt dat zij hun cliënten zo goed mogelijk van dienst zijn (Kolthoff, Loyens \& Verhage 2016). Door dit spanningsveld kan het werk van street-level bureaucrats stress veroorzaken. $\mathrm{Zij}$ moeten namelijk vaak onder hoge tijdsdruk beslissingen nemen die zeer verstrekkende gevolgen voor hun cliënten kunnen hebben, maar beschikken lang niet altijd over alle informatie en middelen die nodig zijn om zich een goed oordeel te kunnen vormen over de rechten of aanspraken die hun cliënten menen te hebben. Om met deze tijdsdruk en dit gebrek aan middelen en informatie om te gaan en toch tijdig tot een beslissing te kunnen komen, maken veel street-level bureaucrats volgens Lipsky (1980, 2010) gebruik van twee typen copingstrategieën: routines (d.w.z. handelswijzen die het werk gemakkelijker maken) en heuristieken ${ }^{9}$ (d.w.z. intuïtieve beslisregels, die bewust of onbewust gebruikt worden om het beslisproces te vergemakkelijken; zie Gigerenzer \& Gaissmaier 2011). Een routine zou bijvoorbeeld kunnen zijn dat men bepaalde cliënten te snel hun zin geeft of hen juist ontmoedigt om

9 Lipsky duidt heuristieken aan met de term 'simplificaties'. Omdat het begrip 'heuristieken' vaker gebezigd wordt in de beslisliteratuur, geven wij de voorkeur aan deze term. 
gebruik te maken van de dienstverlening die de organisatie aanbiedt (Doornbos 2011; Kolthoff et al. 2016). Bij een heuristiek kan men denken aan het bevoor- of benadelen van cliënten die aan bepaalde stereotypen voldoen (Lipsky 1980, 2010).

Voor de organisatie waarvoor street-level bureaucrats werken kan de gebruikmaking van copingstrategieën twee ongewenste gevolgen hebben: (1) dat er ongelijkheid ontstaat in de manieren waarop verschillende cliënten door de organisatie worden behandeld en (2) dat wordt gehandeld in strijd met de doelen die de organisatie zich heeft gesteld (bijv. het verlenen van bepaalde diensten) en het belang dat zij heeft bij het behalen van deze doelen (bijv. het verkrijgen van overheidsfinanciering; Kolthoff et al. 2016).

\subsection{Eerder onderzoek}

Hoewel de beslispraktijk van het schadefonds nog nooit onderwerp van wetenschappelijk onderzoek is geweest, is behoorlijk veel onderzoek verricht dat relevant is voor de onderhavige studie. Er is bijvoorbeeld onderzoek verricht naar de vraag hoe street-level bureaucrats omgaan met hun beleidsvrijheid. Veel van dit onderzoek is uitgevoerd binnen organisaties die deel uitmaken van de publieke sector, zoals de Nederlandse studie van Raaphorst (2017) over hoe ambtenaren van de Belastingdienst de betrouwbaarheid van een belastingaangifte bepalen. Daarnaast zien we steeds meer criminologisch onderzoek naar hoe actoren in de strafrechtspleging met hun discretionaire bevoegdheid omgaan, zoals de studie van Geenen e.a. (2016) over het handelen van groepsleiders in een justitiële jeugdinrichting, die van Bosma e.a. (2017) over hoe trajectbegeleiders in de gevangenis bepalen welke gedetineerden tot een behandelprogramma werden toegelaten, en de studie van Dekkers (2019) over hoe de Koninklijke Nederlandse Marechaussee bij de grensbewaking beslist welke voertuigen onderzocht worden.

Een andere tak van onderzoek die relevant is voor deze studie gaat over factoren die samenhangen met geloofwaardigheidsoordelen over slachtoffers van criminaliteit die bekend zijn bij politie en justitie en waarin de invloed van zowel routines als heuristieken op zulke oordelen is onderzocht. Een routine die politierechercheurs regelmatig gebruiken om de geloofwaardigheid van een aangever te beoordelen is het anticiperen op beslissingen die in een later stadium worden genomen. In de literatuur wordt deze routine aangeduid met de term 'downstream orientation' (Frohmann 1997). Meer concreet houdt deze routine in dat rechercheurs zich tijdens het opsporingsonderzoek afvragen of de verklaring van het slachtoffer voldoende aanknopingspunten biedt om de vermeende dader te vervolgen. Indien zij denken dat dat niet het geval is, dan zullen zij de zaak niet overdragen aan de officier van justitie met als argument dat het verhaal van het slachtoffer ongeloofwaardig is, zelfs wanneer het slachtoffer oprecht op hen overkwam (bijv. Campbell, Menaker \& King 2015). Iets vergelijkbaars zou voor beoordelingen over aannemelijkheid kunnen gelden; verondersteld zou kunnen worden dat de juristen van het secretariaat SGM die in primo moeten beslissen op een verzoek tot tegemoetkoming in schade daarbij anticiperen op de houdbaarheid van hun beslissing in bezwaar. 
Een heuristiek die vaak wordt gebruikt bij geloofwaardigheidsoordelen over slachtoffers is de affectheuristiek. Volgens deze heuristiek laten mensen zich bij het nemen van beslissingen leiden door hun gevoelens (Finucane, Alhakami \& Slovic 2000). Gebruikmaking van deze heuristiek kan onder andere voorkomen wanneer een beoordelaar wordt geconfronteerd met uitingen van emotie door het slachtoffer (voor een overzicht van studies waarin dit is aangetoond, zie Wrede 2015). Door de confrontatie met het emotionele leed dat het slachtoffer ervaart, kan de beoordelaar sympathie voor het slachtoffer krijgen en zijn of haar verhaal sneller geloofwaardig achten. In de literatuur wordt dit het 'emotional victim effect' genoemd (Ask \& Landström 2010). Bij de aannemelijkheidsbeoordelingen door de beslissers van het schadefonds zou iets soortgelijks kunnen gebeuren. De juristen van het secretariaat SGM en de leden van de commissie SGM kunnen door het persoonlijk contact dat zij met de aanvrager hebben namelijk geconfronteerd worden met diens emoties. Verondersteld zou kunnen worden dat dit hun sympathie voor de aanvrager vergroot of verkleint en van invloed is op hun aannemelijkheidsoordeel. ${ }^{10}$ Gevoelens van sympathie stimuleren mensen namelijk om anderen te helpen (vgl. Lerner 1970, 1980; cf. Lerner \& Simmons 1966).

Een andere heuristiek die vaak wordt gebruikt bij geloofwaardigheidsoordelen over slachtoffers is de representativiteitsheuristiek. Volgens deze heuristiek laten mensen zich bij het nemen van beslissingen ook leiden door stereotypen (Kahneman \& Tversky 1972). Bij beslissingen over slachtoffergeloofwaardigheid gaat het dan om het stereotiepe beeld dat mensen hebben van een geloofwaardig slachtoffer. In de literatuur wordt dit stereotiepe beeld het 'het ideale slachtoffer' genoemd (Christie 1986). Eerder onderzoek suggereert dat er verschillende factoren zijn die een slachtoffer idealer en daarmee geloofwaardiger maken in de beleving van de beoordelaar, zoals vrouwelijk geslacht (bijv. Nagle, Brodsky \& Weeter 2015), een lage (bijv. McCauly \& Parker 2001) of juist een hoge leeftijd (bijv. Mueller-Johnson, Toglia, Sweeney \& Ceci 2007) en een blanke huidskleur (bijv. Mulder \& Winiel 1996; Bottoms, Davis \& Epstein 2004). Hiernaast zijn er ook factoren die een slachtoffer minder geloofwaardig maken. Te denken valt bijvoorbeeld aan vermeende betrokkenheid bij criminele of dubieuze praktijken (Hine \& Murphy 2017; Sleath \& Bull 2017) en uiterlijke kenmerken, zoals het hebben van overgewicht en fysieke onaantrekkelijkheid (bijv. Clarke \& Stermac 2011; Vrij \& Firmin 2001; Yamawaki, Riley, Rasmussen \& Cook 2015). Mogelijk spelen deze of andere voor de geloofwaardigheidsbeoordeling vaak irrelevante factoren ook een rol in de beslispraktijk van het schadefonds.

\subsection{Onderzoeksvragen}

Zoals we ook in paragraaf 1.2 opmerkten, staat in dit onderzoek de vraag centraal hoe de juristen van het secretariaat SGM en de leden van de commissie SGM omgaan met de discretionaire ruimte die zij hebben bij het nemen van een beslissing tot toekenning of afwijzing van een verzoek tot tegemoetkoming in schade. 
Gelet op het voorgaande, zullen we deze vraag beantwoorden aan de hand van de volgende twee deelvragen:

1 Kunnen de juristen van het secretariaat SGM en de leden van de commissie SGM op grond van het werk van Lipsky $(1980,2000)$ worden aangemerkt als street-level bureaucrats? Deze vraag zullen we beantwoorden aan de hand van de volgende vijf subvragen:

a Zijn de juristen van het secretariaat SGM en de leden de commissie SGM professionals?

b Zijn zij werkzaam in de publieke sector?

c Staan zij in direct contact met burgers die zich niet geheel vrijwillig tot de organisatie waarvoor zij werkzaam zijn hebben gewend?

d Hebben zij discretionaire ruimte bij het nemen van hun beslissingen?

e Ervaren zij bij het nemen van hun beslissingen druk door gebrek aan tijd, informatie en middelen?

2 Indien het antwoord op de eerste vraag bevestigend luidt, gebruiken zij dan, zoals op grond van empirisch onderzoek naar geloofwaardigheidsoordelen kan worden verwacht, de routine 'downstream orientation' en de affect- en representativiteitsheuristiek als copingstrategieën in situaties die worden gekenmerkt door tijdsdruk en/of gebrek aan tijd en/of middelen? Om deze vraag te beantwoorden, zullen we in kaart brengen welke routines en heuristieken de juristen van het secretariaat SGM en de leden van de commissie SGM gebruiken bij de aannemelijkheidsbeoordeling.

\section{Methode}

Voor de beantwoording van de subvragen a tot en met $d$ van de eerste onderzoeksvraag hebben we enkele documenten bestudeerd (de website van schadefonds, de Wet Schadefonds Geweldsmisdrijven en de beleidsbundel) en hebben we drie informatieve gesprekken met medewerkers van het schadefonds gevoerd (één gesprek met de directeur, een commissielid en een beleidsmedewerker, één gesprek met een teamleider en één gesprek met een jurist van het secretariaat SGM). De nadruk van het onderzoek ligt op de beantwoording van subvraag e over de ervaren druk en de tweede onderzoeksvraag over de gehanteerde copingstrategieën. Voor de beantwoording van deze vragen is ervoor gekozen om interviews af te nemen onder juristen van het secretariaat SGM en leden van de commissie SGM. Diepte-interviews met open vragen zijn immers een geschikte methode om erachter te komen wat zich in de hoofden van de beslissers afspeelt, zoals in hoeverre zij druk ervaren door tijd- en informatie- en middelengebrek, en welke routines en heuristieken zij - naar eigen zeggen - gebruiken om met deze druk om te gaan. In totaal hebben we vijftien interviews afgenomen: elf interviews met juristen van het secretariaat SGM en vier interviews met leden van de commissie SGM. Van de geïnterviewde juristen waren er zeven vrouw en vier man, van de commissieleden waren er één vrouw en drie man. Alle geïnterviewden hadden ruime ervaring met de aannemelijkheidsbeoordeling en waren tussen anderhalf jaar en dertien jaar aan het schadefonds verbonden. De interviews von- 
den plaats bij het schadefonds in Den Haag in de periode tussen 10 oktober 2017 en 3 november 2017 op basis van een semigestructureerd interviewprotocol. De interviews zijn verbatim uitgewerkt. $\mathrm{Na}$ uitwerking zijn alle geïnterviewden in de gelegenheid gesteld de tekst te corrigeren op feitelijke onjuistheden en zijn de gespreksverslagen geanalyseerd met behulp van het computerprogramma ATLAS.ti. Hierbij is gebruikgemaakt van drie manieren van coderen. In eerste instantie zijn op basis van het interviewprotocol labels opgesteld en toegekend aan fragmenten uit de interviews (open coderen). Vervolgens zijn de fragmenten met dezelfde labels met elkaar vergeleken om onderlinge verschillen en overeenkomsten te kunnen vaststellen en specifiekere labels te kunnen opstellen (axiaal coderen). Ten slotte zijn de verschillende labels nogmaals onderling vergeleken en zijn deze nog verder uitgesplitst of samengevoegd (selectief coderen; cf. Decorte 2016).

\section{Resultaten}

De resultaten zullen worden besproken aan de hand van de onderzoeksvragen. In paragraaf 3.1 zal worden ingegaan op de vraag of de juristen van het secretariaat SGM en de leden van de commissie SGM kunnen worden aangemerkt als streetlevel bureaucrats. Vervolgens zal in paragraaf 3.2 worden stilgestaan bij de vraag of zij - naar hun eigen zeggen - gebruikmaken van de routine 'downstream orientation' en de affect- en representativiteitsheuristiek als copingstrategieën in situaties die worden gekenmerkt door tijdsdruk en/of een gebrek aan informatie en/of middelen.

\subsection{Beslissers van het schadefonds als street-level bureaucrats}

Volgens Lipsky $(1980,2000)$ zijn street-level bureaucrats (a) professionals, (b) die werkzaam zijn in de publieke sector, (c) in direct contact met burgers staan die zich niet geheel vrijwillig hebben gewend tot de organisatie waarvoor zij werkzaam zijn, (d) discretionaire ruimte hebben bij het vertalen van beleid naar concrete acties, (e) en tijdsdruk ervaren alsmede een gebrek aan informatie en middelen. De juristen van het secretariaat SGM en de leden van de commissie SGM lijken aan al deze kenmerken in een bepaalde mate te voldoen. Zij hebben namelijk vrijwel allemaal een universitaire rechtenopleiding of een andere relevante universitaire opleiding gevolgd. Zij kunnen dus worden aangemerkt als professionals. Dit bleek onder meer uit de informatieve gesprekken. Zij zijn bovendien werkzaam in de publieke sector. Uit de Wet Schadefonds Geweldsmisdrijven volgt namelijk dat het schadefonds een publiekrechtelijke rechtspersoon is en wordt gefinancierd door het Ministerie van Justitie en Veiligheid. Ook hebben zij regelmatig contact met burgers. Volgens de website van het schadefonds wordt voor de meeste aanvragen namelijk telefonisch contact met de aanvrager opgenomen ${ }^{11}$ en aanvragers die in bezwaar gaan tegen de primaire beslissing op de aanvraag

11 Dit volgt uit de website van het schadefonds (zie www.schadefonds.nl/wat-gebeurt-met-uwaanvraag). 
moeten in beginsel in de gelegenheid worden gesteld om hun bezwaar tijdens een hoorzitting toe te lichten. ${ }^{12}$ Degenen die een aanvraag indienen bij het schadefonds doen dit bovendien meestal niet geheel vrijwillig; het schadefonds biedt hen namelijk de enige mogelijkheid om nog iets van de door het misdrijf geleden schade vergoed te krijgen. Tevens lijken de juristen van het secretariaat SGM en de leden van de commissie SGM discretionaire bevoegdheid te hebben bij het vertalen van beleid naar concrete acties; zij moeten immers de aanwijzingen uit de beleidsbundel toepassen op concrete aanvragen. Aan de eerste vier kenmerken van een street-level bureaucrat lijken zij dus, in mindere of meerdere mate, te voldoen. Zoals gezegd, hebben we aan de hand van de interviews trachten te beoordelen of zij ook aan het vijfde kenmerk voldoen, doordat zij bij de uitoefening van hun werkzaamheden tijdsdruk ervaren en kampen met een gebrek aan informatie en middelen.

\subsubsection{Tijdsdruk}

De juristen en commissieleden zijn gebonden aan de beslistermijnen van de Algemene wet bestuursrecht (hierna: Awb). Dit laatste betekent dat op elke aanvraag binnen een termijn van 26 weken na ontvangst van de aanvraag moet worden beslist ${ }^{13}$ en dat bezwaarschriften binnen 12 weken moeten worden afgehandeld. ${ }^{14}$ Volgens de geïnterviewde juristen van het secretariaat SGM leiden de beslistermijnen van de Awb in de meeste gevallen bij henzelf niet tot tijdsdruk, maar merken zij wel dat collega's het gevoel hebben onder tijdsdruk beslissingen te moeten nemen. Eén van hen zei hierover:

'Ik weet niet of het door tijdsdruk is, ik weet alleen dat werk ... stress of werkdrukbeleving eigenlijk al jaren een item is en dat er mensen zijn die daar ... ja, erg zenuwachtig van worden.' [interview 1 , jurist secretariaat SGM, man ${ }^{15}$ ]

In zaken waarin informatie bij gemachtigden van aanvragers of ketenpartners van het schadefonds (bijv. de politie of het Openbaar Ministerie) is opgevraagd, kan bij de juristen van het secretariaat SGM soms wel tijdsdruk ontstaan. ${ }^{16}$ In sommige gevallen wordt opgevraagde informatie namelijk heel laat of pas na herhaaldelijk rappelleren aangeleverd. Over het (te) laat aanleveren van informatie door de politie en/of het Openbaar Ministerie werd door een van de geïnterviewde juristen het volgende gezegd:

Dit is bepaald in art. 7:2 van de Algemene wet bestuursrecht (hierna: Awb). In art. 7:3 Awb worden evenwel enkele uitzonderingsgronden geformuleerd.

13 Dit is bepaald in art. 3:18 lid 1 Awb.

14 Dit is bepaald in art. 7:10 lid 1 Awb.

15 Omwille van hun privacy geven we bij de citaten alleen informatie over het nummer van het interview, de functie van de beslisser (jurist secretariaat SGM of lid commissie SGM) en diens geslacht.

16 Opmerkelijk is dat geen van de geïnterviewden aangaf bij (te) late aanlevering van stukken gebruik te maken van de door art. 4:15 Awb geboden mogelijkheid om de beslistermijn op te schorten. 
'Het is soms meer frustrerend, ook als je heel lang wacht op iets en het komt maar niet. Terwijl justitie en politie ook gewoon partners zijn van ons. En we recht hebben op die informatie. Maar er gaat soms zo lang overheen. En dan belt het slachtoffer weer op want die denkt: "Waar blijft mijn beslissing?"' [interview 15, jurist secretariaat SGM, vrouw]

Een andere reden waardoor tijdsdruk kan ontstaan, is de hoeveelheid aanvragen die de juristen van het secretariaat SGM moeten afhandelen. Dit zijn er 28 per maand voor een fulltime medewerker. Volgens de geïnterviewde juristen leidt dit bij sommige jonge en nieuwe, onervaren medewerkers tot tijdsdruk. Dit blijkt onder andere tijdens verplichte consultatiesessies en tijdens de voorbereiding van bezwaarzaken. Een van de geïnterviewde juristen merkte hier het volgende over op:

'Maar als je verplicht consult hebt, waar je een heleboel van oude naar nieuwe medewerkers krijgt, dat je merkt, oké het kan zijn dat je hierover hebt nagedacht, je hebt er niet uitgehaald wat ik denk dat erin zit. Het kan zijn omdat je het gewoon niet ziet, kan ook zijn omdat je haast hebt.' [interview 1, jurist secretariaat SGM, man]

De geïnterviewde leden van de commissie SGM lijken geen tijdsdruk te ervaren. $\mathrm{Zij}$ behandelen uitsluitend bezwaarzaken en worden daarbij ondersteund door een ervaren jurist van het secretariaat SGM; deze bereidt de zaak en een eventuele hoorzitting voor en concipieert de beslissing op bezwaar.

\subsubsection{Gebrek aan informatie en middelen}

Het niet tijdig aanleveren van relevante informatie door ketenpartners kan leiden tot tijdsdruk bij de aannemelijkheidsbeoordeling, maar het komt ook regelmatig voor dat informatie die relevant is voor de aannemelijkheidsbeoordeling überhaupt niet voorhanden is. Of dit een probleem oplevert voor de aannemelijkheidsbeoordeling, hangt af van de moeilijkheidsgraad van de aanvraag. Het schadefonds heeft namelijk niet de bevoegdheid en middelen om eigen onderzoek te verrichten en is dus in grote mate afhankelijk van de informatie die door aanvragers en ketenpartners wordt aangeleverd. Grosso modo kan een onderscheid worden gemaakt tussen eenvoudige en complexe aanvragen; maar liefst twaalf van de in totaal vijftien geïnterviewden maakten dit onderscheid. Bij de eerste categorie speelt gebrek aan informatie en bevoegdheden en middelen nauwelijks een rol in de aannemelijkheidbeoordeling, bij de tweede des te meer.

\section{- Eenvoudige aanvragen}

Volgens de geïnterviewden is het merendeel van de zaken eenvoudig van aard. Eenvoudige aanvragen kunnen worden onderscheiden in drie categorieën. De eerste categorie betreft aanvragen waarbij het proces-verbaal van aangifte voldoende informatie geeft voor de aannemelijkheidsbeoordeling. Omdat het proces-verbaal van aangifte voor het schadefonds leidend is in de aannemelijkheidsbeoordeling, 
leiden zulke aanvragen doorgaans snel tot een beslissing. Eén van de geïnterviewde juristen van het secretariaat SGM zei hier het volgende over:

' $J a$, de weergave is die het slachtoffer zelf geeft, eigenlijk. En in principe gaan we ook uit van de opgave van het slachtoffer en dan is het heel vaak, omdat die aangifte er is, omdat er dan ook, ja een heel kleine validatie inzit van, valse aangifte doen, dat is strafbaar. Dus ... dat is voor ons wel iets dat we daar dan wel vanuit durven gaan, als je dat bij de politie vertelt. Die stelt soms ook vragen in de aangifte, dat je denkt van nou, dan krijg je al een heel helder beeld van hoe dat soms is gegaan.' [interview 15, jurist secretariaat SGM, vrouw]

De tweede categorie eenvoudige aanvragen betreft aanvragen waarbij geen ernstig letsel in de zin van de Wet Schadefonds Geweldsmisdrijven op basis van objectieve medische informatie kan worden vastgesteld en dergelijk letsel op basis van de beleidsbundel niet kan worden voorondersteld. Zulke aanvragen leiden altijd tot een afwijzende beslissing. Een van de geïnterviewde juristen van het secretariaat SGM verwoordde dit als volgt:

'Iemand die door een klap van een mishandeling alleen blauwe plekken heeft opgelopen en daarvoor niet in behandeling is, dat noemen wij dan eenvoudige zaken [geen] ernstig letsel [...].' [interview 2, jurist secretariaat SGM, vrouw]

De laatste categorie eenvoudige zaken betreft aanvragen waarbij onmiddellijk duidelijk is dat het slachtoffer geen enkele rol heeft gespeeld in de aanleiding, toedracht en omstandigheden van het geweldsmisdrijf. Dat is bijvoorbeeld het geval bij zedenmisdrijven met minderjarigen (waarvan aangifte is gedaan) en winkel- en sommige woningovervallen. Door een van de geïnterviewde juristen van het secretariaat SGM werd hier het volgende over gezegd:

'De makkelijke beoordelingen zijn eigenlijk de beoordelingen waarin de onschuld van het slachtoffer, de pech bijvoorbeeld die iemand kan hebben, er vanaf spettert. Dat zie je bij winkelovervallen bijvoorbeeld, werknemers die worden overvallen, zaken met misbruik van jonge kinderen [waarvan geen aangifte is gedaan], dat is allemaal niet zo ingewikkeld, daar hoef je je weinig af te vragen.' [interview 1 , jurist secretariaat SGM, man]

\section{- Complexe aanvragen}

Hoewel het merendeel van de aanvragen eenvoudig van aard is, komen ook complexe aanvragen regelmatig voor. Ook deze aanvragen kunnen worden onderscheiden in drie categorieën. De eerste categorie betreft aanvragen die betrekking hebben op een zedenmisdrijf met een minderjarige of een geval van huiselijk geweld waarvan geen aangifte is gedaan. Anders dan bij aanvragen wegens andere geweldsdelicten, wordt het doen van aangifte in zulke gevallen niet vereist. Voor het slachtoffer kan dat namelijk bezwaarlijk zijn vanwege de loyaliteit die hij of zij jegens de dader voelt. Wel moet er contact zijn geweest met de politie of een 
andere (overheids)instantie (bijv. een instelling op het gebied van jeugd- of geestelijke gezondheidszorg). Is dat niet gebeurd, dan kan de aannemelijkheid van het geweldsmisdrijf meestal sowieso niet worden aangenomen. Dit blijkt onder meer uit het volgende citaat:

'(...) als er dan geen contact is geweest met de politie (of een andere instantie), dan wordt het wel ... lastig om een geweldsmisdrijf aannemelijk te achten (...)' [interview 7, jurist secretariaat SGM, man]

Om verschillende redenen kan het lastig zijn om zedenmisdrijven met minderjarigen of gevallen van huiselijk geweld aannemelijk te achten. Wat vaak voorkomt, is dat men alleen beschikt over de verklaringen van het slachtoffer. Vanwege het gebrek aan bevoegdheden en middelen tot het verrichten van eigen, aanvullend onderzoek, kan dit het beoordelen van de aannemelijkheid erg complex maken. Dit blijkt onder meer uit het volgende citaat:

'(...) want als je gewoon strafrechtelijk onderzoek hebt, kan je altijd bellen, ligt er onderzoek, zijn er vaak getuigen voor, is er goede informatie voor, maar huiselijk geweld ... nu zijn er allemaal losse verhalen, je weet natuurlijk niet goed wat de situatie thuis was. Heeft de aanvraagster bijvoorbeeld ook geweld gebruikt tegen haar echtgenoot? Daar is natuurlijk geen navraag van gedaan ... en ja, dan mis je toch wel een gedeelte van het verhaal en je kan bijvoorbeeld ook nog vragen, dat heb je ook bij huiselijk geweld, dat mensen zeggen dat ze seksueel misbruikt zijn door hun echtgenoot, ja moet je dat dan ook aannemelijk gaan achten omdat je dat ene stukje geweld aannemelijk hebt geacht?' [interview 3, jurist secretariaat SGM, man]

Overigens kan in het geval van seksueel misbruik van kinderen ook informatie van een medicus voldoende zijn om de verklaring van de aanvrager te onderbouwen en de aannemelijkheid vast te stellen. Dit bleek na afloop van de interviews uit een e-mail die door een vrouwelijke medewerker van het schadefonds aan de tweede auteur werd gestuurd.

De tweede categorie complexe aanvragen betreft aanvragen waarbij op basis van het proces-verbaal van aangifte niet duidelijk is wat de rol van de aanvrager is geweest in de aanleiding, toedracht en omstandigheden van het geweldsmisdrijf. Vooral wanneer de aanvrager op straat is neergeschoten, rijst vaak de vraag of het ging om een afrekening in het criminele circuit. Een van de geïnterviewde juristen zei hier het volgende over:

'Ja, waarom, dat zijn over het algemeen de dingen die je in de media ook terugziet, maar ook de dingen waarvan je uit ervaring toch wel leert dat daar vaak toch wel meer achter zit. Tenzij je erachter komt, je hebt geloof ik een hele hoop liquidaties gehad in Amsterdam en dat er dan ook iemand, nou ja persoonsverwisseling, die dingen heb je ook. Maar dan ga je wel kijken, waar was hier sprake van.' [interview 2, jurist secretariaat SGM, vrouw] 
Ook wanneer de aanvrager het slachtoffer van uitgaansgeweld is geworden, is het vaak lastig om de aanleiding, toedracht en omstandigheden van het geweldsmisdrijf vast te stellen. De vraag rijst dan namelijk bijna altijd of de aanvrager ook zelf geweld heeft gebruikt. Dit blijkt onder meer uit het volgende citaat:

'Ja, dat soort kwesties komen meest pregnant naar voren in uitgaansgeweld. Want daarvan is het heel vaak onduidelijk wie wat wanneer heeft gedaan. Er zijn meestal meerdere mensen bij betrokken, meerdere verdachten, meerdere slachtoffers, over en weer aangiftes ... ja ... dan moet er wel chocola van worden gemaakt wat er precies is gebeurd. Omdat die aanleiding, toedracht en omstandigheden heel belangrijk zijn voor het beoordelen van het eigen aandeel. Als die aanleiding, toedracht en omstandigheden niet duidelijk zijn, dan is het de vraag of ... je het eigen aandeel van het slachtoffer voldoende kunt beoordelen en eventueel kunt uitsluiten.' [interview 7, jurist secretariaat SGM, man]

Ten slotte bestaat ook bij burenruzies vaak onduidelijkheid over de aanleiding, toedracht en omstandigheden van het geweldsmisdrijf. De vraag kan dan namelijk rijzen of de aanvrager de ruzie met de buurman of -vrouw zelf heeft uitgelokt. Hierover werd door een van de leden van de commissie SGM het volgende gezegd:

'Waar twee kijven ... hè, [lacht] er bestaat best een kans dat er twee schuld hebben, maar je ziet er maar één. Die twee buren komen hier niet samen ...' [interview 10, lid commissie SGM, man]

De derde categorie complexe aanvragen betreft aanvragen wegens slachtofferschap van mensenhandel. In zulke gevallen kan niet altijd worden afgegaan op het proces-verbaal van aangifte, omdat de aangifte voor slachtoffers van mensenhandel een instrument is om in aanmerking te komen voor een tijdelijke verblijfsvergunning op grond van de zogenoemde B8/3-regeling. ${ }^{17}$ Omdat zij een belang kunnen hebben bij het doen van aangifte, kan deze vals zijn. Een van de geïnterviewde juristen van het secretariaat SGM merkte hier het volgende over op:

'(...) Binnen de mensenhandelzaken zegt de aangifte ook niet alles. Daarin is ook van belang wat de politie daarmee kan of ervan vindt. En daarbij kijken we ook wel naar contra-indicaties. Er zijn een hele hoop zaken die ook wel worden afgewezen en dan hebben we het over zaken waarbij er sprake is van Afrikaanse, Noord-Afrikaanse slachtoffers ... die nou ja, naar Nederland komen en die bij ons ... die aangifte doen van mensenhandel. Op het moment dat je aangifte doet van mensenhandel, krijg je ook een tijdelijke verblijfsstatus en zolang je eigenlijk het onderzoek ... doet. Dan is het verbonden aan die mensenhandelaangifte die je doet. B9, B8-regeling is dat volgens mij. Ja dat zijn bij ons wel zaken waarin we wat nauwkeuriger kijken naar wat er nou 
precies aan de hand is. En dat heeft er ook mee te maken dat er vermoedens zijn of in ieder geval vermoedens waren dat die regeling werd misbruikt ... [interview 5, jurist secretariaat SGM, vrouw]

Ten slotte kan de complexiteit in mensenhandelzaken er ook uit bestaan dat het proces-verbaal van aangifte te weinig opsporingsindicaties voor de politie bevatte om een strafrechtelijk onderzoek te starten. Het schadefonds moet dan zelf inschatten of er desondanks toch sprake was van slachtofferschap. Vanwege het gebrek aan bevoegdheden en middelen tot het verrichten van eigen, aanvullend onderzoek, is dit bepaald geen eenvoudige opgave. Dit bleek uit de eerder genoemde e-mail die een vrouwelijke medewerker van het schadefonds na afloop van de interviews aan de tweede auteur heeft gestuurd.

Op basis van de interviews kan worden geconcludeerd dat de juristen van het secretariaat SGM en de leden van de commissie SGM in een bepaalde mate ook voldoen aan het vijfde kenmerk van een street-level bureaucrat, namelijk dat zij bij de uitoefening van hun werkzaamheden tijdsdruk ervaren en soms kampen met een gebrek informatie en middelen. Met name de juristen lijken regelmatig tijdsdruk te ervaren en zowel de juristen als de commissieleden zijn van mening dat gebrek aan informatie en bevoegdheden en middelen (in het bijzonder het ontbreken van bevoegdheden en middelen tot het doen van eigen, aanvullend onderzoek) de uitoefening van hun werkzaamheden kan belemmeren, met name in complexe zaken. Het is daarom gerechtvaardigd om de vervolgvraag te stellen: Gebruiken zij de routine 'downstream orientation' en de affect- en representativiteitsheuristiek als copingstrategieën in situaties waarin gebrek aan tijd, informatie of middelen een rol speelt?

\subsection{Copingstrategieën}

\subsubsection{Routines}

Een routine waarvan de juristen van het secretariaat SGM soms gebruik lijken te maken om tijdig, dat wil zeggen binnen de wettelijke beslistermijn, een beslissing te kunnen nemen is het opnemen van een herzieningsclausule in de tekst van de beslissing; twee van de geïnterviewden noemden deze mogelijkheid. Zij wijzen de aanvraag dan af wegens het ontbreken van voldoende informatie om het geweldsmisdrijf aannemelijk te kunnen achten. Door in de tekst van de beslissing een herzieningsclausule op te nemen, wordt voorkomen dat de aanvrager in bezwaar gaat tegen de beslissing. Een van de geïnterviewde juristen lichtte deze routine als volgt toe:

'Maar er, het is ook best wel een gemakkelijke oplossing, want stel je voor dat je niet de juiste informatie krijgt van het OM, dan kan je dat gewoon in de beslissing opschrijven, dat je voorlopig afwijst omdat de aanleiding of iets dergelijks niet duidelijk is. Ik heb dat gisteren nog bij een zaak gedaan waarbij valt te verwachten dat op de zitting, de verdachte een beroep doet op noodweer. Dus dan leg ik dat gewoon uit dat we op dit moment geen stukken krij- 
gen en dat het onderzoek nog loopt, waaruit moet blijken hoe betrouwbaar die verklaring van de verdachte is en dan neem je een herzieningsclausule op, mochten ze er later op terug willen komen, mocht de aanleiding, toedracht wel duidelijk zijn, bijvoorbeeld door een veroordeling door de rechtbank voor een geweldsmisdrijf.' [interview 3, jurist secretariaat SGM, man]

Om tijdig een beslissing te kunnen nemen, komt ook de routine voor, dat de aanvraag wordt toegekend zonder dat de aanvrager, zoals de bedoeling is, wordt gebeld. Dat gebeurt echter uitsluitend indien er geen twijfel bestaat over de aannemelijkheid.

'(...) dat ik gewoon niet meer elke zaak bel. En dat hoor ik van wel meer collega's.' [interview 8 , jurist secretariaat SGM, vrouw]

Een routine die soms gebruikt wordt om met informatiegebrek om te gaan is het anticiperen op een mogelijke bezwaarprocedure. Deze routine vertoont sterke gelijkenissen met de routine 'downstream orientation' (zie Frohmann 1991). De aanvraag wordt dan toegekend, omdat men verwacht dat een afwijzende beslissing in bezwaar geen stand zal houden. Een van de geïnterviewde juristen van het secretariaat SGM zei over deze routine het volgende:

'Maar je hebt dus soms gevallen van senioren die zeggen van ja, ik vind, ik weet het niet helemaal, maar mocht deze persoon in bezwaar gaan, ja, dan gaat het toch gegrond, dus doe maar in primo nu toewijzen. En dat vind ik eigenlijk best erg op een manier, want dan loont het haast om in bezwaar te gaan om het in bezwaar gaan.' [interview 8 , jurist secretariaat SGM, man]

\subsubsection{Heuristieken}

Naast routines maken de juristen van het secretariaat SGM en de leden van de commissie SGM ook gebruik van heuristieken om de aannemelijkheid van een aanvraag te beoordelen. Daarbij geldt wel dat dit volgens de geïnterviewde juristen en commissieleden in belangrijke mate beperkt is tot bezwaarprocedures waarin de aanvrager gehoord wordt over zijn bezwaar. In zo'n geval wordt de aanvrager namelijk gezien door de jurist van het secretariaat SGM die verslag legt van de hoorzitting en de beslissing op bezwaar concipieert en door het commissielid dat de hoorzitting voorzit. Dit persoonlijke contact met de aanvrager kan volgens een van de geïnterviewde commissieleden van invloed zijn op de beoordeling van de aannemelijkheid. In de meeste gevallen heeft dit te maken met aanvullende informatie die tijdens de hoorzitting wordt overgelegd en relevant is voor de beoordeling van de aannemelijkheid. Daarnaast komt het echter ook voor dat de indruk die de aanvrager tijdens de hoorzitting achterlaat van invloed is op de aannemelijkheidsbeoordeling. Een van de geïnterviewde commissieleden zei hier het volgende over:

'Tuurlijk heeft dat je met iemand spreekt, dat [je] kan ruiken of hij zweet of niet, te maken met of je iemand ziet. En we kunnen met zijn allen zeggen dat 
dat marginaal is, van ja [...] Ja het speelt een hartstikke grote rol, hoe je mensen percipieert. En wat je gelooft ... ja, tuurlijk.' [interview 14, lid commissie SGM, man]

Opmerkelijk is dat de geïnterviewde juristen van het secretariaat SGM van mening zijn dat vooral de leden van de commissie SGM zich bij de beoordeling van de aannemelijkheid laten beïnvloeden door het persoonlijke contact met de aanvrager tijdens de hoorzitting en dat deze commissieleden minder streng zijn bij de aannemelijkheidsbeoordeling dan zijzelf. Blijkens het volgende citaat heeft dit wellicht te maken met gebruikmaking van de affectheuristiek:

'Dan proberen [we] de discussie op gang te krijgen. Dat is soms lastig [...] ja, daar moet ik eerlijk in zijn, dat is soms lastig, [denkt na] omdat commissieleden soms, wat ik zei, ontvankelijk zijn voor [...] die dingen die op de hoorzitting dan bijvoorbeeld naar voren zijn gekomen en wat voor impact dat op mensen heeft, maar nogmaals, wij zien dat soort zaken gewoon heel veel en we willen daar één lijn in trekken.' [interview 13, jurist secretariaat SGM, vrouw]

Een van de geïnterviewde commissieleden beaamde dat commissieleden in bezwaar soms met een welwillender oog naar een aanvraag kijken dan de juristen van het secretariaat SGM. Anders dan in het citaat wordt gesuggereerd, heeft dit volgens het betreffende commissielid echter niet te maken met de grotere ontvankelijkheid van commissieleden voor de impact die het geweldsmisdrijf op het slachtoffer heeft gehad, maar met hun taak om de solidariteitsfunctie van het schadefonds te bewaken. Die vergt van hen dat zij soms compassie tonen met aanvragers ten aanzien van wie het gevoel heerst dat het niet onterecht zou zijn om hen het voordeel van de twijfel te gunnen. Het commissielid verwoordde deze werkwijze als volgt:

'Het is ook weer het strikt volgen, hoe strikt volg je die justitiële beoordeling. Ja. Die beleidsvrijheid nemen we ook wel een beetje hoor, dus ja. Maar dat is ook echt wel belangrijk denk ik hoor, dat wij die aannemelijkheidstoets echt zo goed mogelijk proberen te benutten om ook de gevallen die in het strafrecht misschien door de ene pijplijn gaan, misschien te zeggen van ja, maar wij zien hier toch net nog iets meer in.' [interview 12, lid commissie SGM, vrouw]

Dat het gebruik van heuristieken zich vooral lijkt te beperken tot bezwaarzaken waarin de aanvrager gebruikmaakt van zijn recht om gehoord te worden, heeft ook te maken met een wijziging van het primaire beslisproces. Tot enkele jaren geleden moest de aanvrager een kopie van zijn paspoort bij de aanvraag voegen. Dat leidde er soms toe dat de jurist die de aanvraag behandelde zich op basis van de paspoortfoto van de aanvrager liet leiden door het stereotiepe beeld dat hij of zij had van een geweldsslachtoffer. Een dergelijke handelswijze duidt op gebruik- 
making van de representativiteitsheuristiek. Eén van de geïnterviewde juristen van het secretariaat SGM verwoordde deze handelswijze als volgt:

'Als iemand van een bepaalde leeftijd dan die aanvraag doet bij ons, vroeger had je ook nog de foto ... van je paspoort hadden we erbij. En dan zagen we zo'n beul van een vent, zagen we op een foto en dan dachten we, ja dáág [...] Maar dat was nog wel iets dat we zeiden van ja, je vertelt het verhaal van het schaap en ik zie hier de grote boze wolf op de foto. En dat is allesbehalve waterdicht, maar dan kreeg je nog weleens gevoel voor de zaak ... een beeld.' [interview 1, jurist secretariaat SGM, man]

Dat stereotiepe beelden - en dus de representativiteitsheuristiek - volgens de geïnterviewden een geringe rol spelen in het primaire beslisproces, wil overigens niet zeggen dat heuristieken nooit in het primaire beslisproces worden gebruikt. Met name in complexe zaken die betrekking hebben op een zedenmisdrijf met een minderjarige of een geval van huiselijk geweld. Zoals we eerder hebben aangegeven, wordt in zulke gevallen geen aangifte vereist en kan de aannemelijkheid ook op basis van andere informatie worden vastgesteld. Blijkens het volgende citaat kan dat leiden tot beïnvloeding door stereotypen en dus gebruikmaking van de representativiteitsheuristiek:

'Maar ook bijvoorbeeld dat we dan een stevige indicatie voor de aanvrager, als zij bij een vrouwenopvang is opgevangen. Als je, je komt niet zomaar terecht in een vrouwenopvang, meestal is het zo streng dat je dan echt in een bedreigende situatie moet zijn, voor de aanvraagster.' [interview 3, jurist secretariaat SGM, man]

Ten slotte verdient het opmerking dat de geringe gebruikmaking van heuristieken niet betekent dat stereotiepe beelden van slachtoffers en daarmee verband houdende factoren geen enkele rol spelen in de aannemelijkheidsbeoordeling. De criteria die volgens de beleidsbundel in acht moeten worden genomen bij de beoordeling van de aannemelijkheid sluiten namelijk in grote mate aan bij het heersende maatschappelijke beeld van een ideaal slachtoffer. Factoren die met dit stereotiepe beeld verband houden, kunnen dus relevant zijn voor de aannemelijkheidsbeoordeling. Eén zo'n factor betreft het doen van aangifte bij de politie. Deze factor houdt nauw verband met een van de kenmerken van ideaal slachtofferschap, namelijk dat het slachtoffer sterk genoeg is om van zich te doen horen en de status van slachtoffer te claimen (vgl. Christie 1986). Een van de geïnterviewde commissieleden lichtte deze rol van het ideale slachtofferbeeld in de aannemelijkheidsbeoordeling als volgt toe:

'Wat wij meemaken is, een slachtoffer kan aangifte doen, maar er kan geen dader zijn, kunnen ze ook gewoon bij ons, maar dan moeten ze wel naar de politie gegaan zijn en zich hebben gemeld bij een psycholoog die bevestigt dat dan en ze hebben er met iemand over gesproken en dan heb je gewoon een zaak. Bij ons. Maar dan heb je gewoon een bikkel en die is wat overkomen, die 
gaat niet naar de politie want die denkt, nou ja weet je wat. En die gaat ook niet naar een psycholoog want die is gewend om dat gewoon te verbijten, maar twee jaar later stort hij in en dan blijkt daaruit, het heeft toch wel heel erg hier mee te maken. Nou ja, dan ben je gewoon te laat. Dan wordt het heel erg moeilijk om hier nog een begin van een bewijs te krijgen. Ja en dat soort mensen hebben hetzelfde meegemaakt hoor. Soms. Dus ja, wij varen, wij hebben echt een ideaal slachtoffer en dat zijn de mensen die gewoon precies doen wat het ideale slachtoffer doet om bij ons een uitkering te krijgen en al die anderen die doen het dan niet ideaal en die krijgen het dan niet meer rond en vallen buiten de boot.' [interview 12, lid commissie SGM, vrouw]

\section{Conclusies}

De onderhavige studie had tot doel te onderzoeken hoe de juristen van het secretariaat SGM en de leden van de commissie SGM omgaan met de discretionaire ruimte die zij hebben bij het nemen van een beslissing tot toekenning of afwijzing van een verzoek tot tegemoetkoming in schade. Om dit te onderzoeken, hebben we verschillende documenten bestudeerd en enkele informatieve gesprekken met medewerkers van het schadefonds gevoerd. Daarnaast hebben we elf juristen van het secretariaat SGM en vier leden van de commissie SGM geïnterviewd. De resultaten van ons onderzoek suggereren dat de beslissers van het schadefonds tot op zekere hoogte kunnen worden gezien als street-level bureaucrats; zij zijn (a) professionals, (b) die werkzaam zijn in de publieke sector, (c) in direct contact met burgers staan die zich niet geheel vrijwillig hebben gewend tot de organisatie waarvoor zij werkzaam zijn, (d) discretionaire ruimte hebben bij het vertalen van beleid naar concrete acties, en (e) sommige van hen ervaren tijdsdruk en een gebrek aan informatie en middelen bij de uitvoering van hun werkzaamheden.

Om met tijdsdruk en een gebrek aan informatie en middelen om te gaan, maken de beslissers van het schadefonds gebruik van verschillende routines en heuristieken. Bij het nemen van primaire beslissingen wordt met name gebruikgemaakt van routines. Indien twijfel bestaat over de aannemelijkheid van de aanvraag, wordt bijvoorbeeld soms toch een tegemoetkoming toegekend wanneer de beslisser in primo verwacht dat een afwijzende beslissing in een eventuele bezwaarprocedure geen stand zal houden ('downstream orientation'). Dit is echter niet de enige routine die bij de beoordeling van primaire aanvragen gebruikt wordt. Om tijdig een beslissing op een aanvraag te kunnen nemen, wordt door de juristen van het secretariaat SGM ook regelmatig een herzieningsclausule in de beslissing opgenomen of wordt door hen afgezien van telefonisch contact met de aanvrager. $^{18}$

Heuristieken lijken bij het nemen van primaire beslissingen niet of nauwelijks gebruikt te worden. Heuristieken worden wel gebruikt bij het nemen van beslis-

Op basis van deze bevinding, die de onderzoekers in juli 2018 aan de commissieleden en de directie van het secretariaat SGM hebben gepresenteerd, is de juristen van het secretariaat SGM verzocht ook in dit soort zaken het beleid te volgen en telefonisch contact met de aanvrager op te nemen. Mogelijk is de gebruikmaking van deze routine hierdoor afgenomen. 
singen op bezwaar, vooral wanneer de aanvrager die bezwaar heeft aangetekend tegen de afwijzende beslissing gebruikmaakt van zijn recht om gehoord te worden. In zulke gevallen kunnen gevoelens van sympathie voor de aanvrager en de mate waarin de aanvrager voldoet aan het ideale slachtofferbeeld een rol spelen in de aannemelijkheidsbeoordeling. Dit duidt op het gebruik van respectievelijk de affect- en de representativiteitsheuristiek. Enige reserve is bij deze conclusies echter wel op zijn plaats, omdat dit onderzoek alleen heuristieken betreft waar de beslisser zich zelf bewust van is. Heuristieken kunnen namelijk ook onbewust een rol spelen tijdens het beslisproces (vgl. Gigerenzer \& Gaissmaier 2011). Aan de hand van de interviewmethode die we voor deze studie hebben gebruikt, is het echter lastig om onbewust gebruikte heuristieken in kaart te brengen.

\section{Discussie}

De bevindingen van dit onderzoek, dat de juristen van het secretariaat en de leden van de commissie SGM tot op zekere hoogte street-level bureaucrats zijn, die vanwege gebrek aan tijd, informatie en middelen terugvallen op verschillende routines en heuristieken, sluiten aan bij bevindingen van andere studies waaruit blijkt dat mensen bij het nemen van beslissingen gebruikmaken van routines als 'downstream orientation' (Frohmann 1997; Campbell, Menaker \& King 2015) en heuristieken als de affectheuristiek. (Finucane, Alhakami \& Slovic 2000) en de representativiteitsheuristiek (Kahneman \& Tversky 1972). Ook zijn er overeenkomsten met andere Nederlandse studies die laten zien hoe street-level bureaucrats invulling geven aan hun discretionaire bevoegdheid. Net als de trajectbegeleiders in de gevangenis uit de studie van Bosma e.a. (2017) laten de beslissers van het schadefonds soms factoren meewegen die niet in het eigen beleid genoemd worden.

De bevindingen sluiten echter op een aantal aspecten minder goed aan op de street-level bureaucracy-theorie. Lipsky's $(1980,2010)$ theorie wordt vaak gebruikt om te verklaren waarom de praktijk afwijkt van het beleid. Leidt de wijze waarop de beslissers van het schadefonds omgaan met hun beslisvrijheid ertoe dat er sprake is van een discrepantie tussen beleid en uitvoeringspraktijk? Leidt het gebruik van routines en heuristieken bijvoorbeeld tot - vanuit een beleidsperspectief ongewenste - willekeur en rechtsongelijkheid tussen aanvragers? Op basis van de onderhavige studie kan deze vraag niet beantwoord worden. Daarvoor is experimenteel onderzoek nodig waarbij dezelfde (fictieve) zaken aan beslissers van het schadefonds worden voorgelegd en daarbij te variëren in omstandigheden die het gebruik van routines en heuristieken stimuleren. Gedacht kan worden aan het voorleggen van een bezwaarzaak waarin de aanvrager wel of geen gebruikmaakt van het recht om gehoord te worden. Op deze manier kan worden onderzocht of persoonlijk contact tijdens de hoorzitting gevoelens van sympathie voor de aanvrager of andere emoties oproept.

Een ander aspect waarop onze studie niet aansluit bij de theorie van Lipsky betreft de aanname dat street-level bureaucrats copingmechanismen hanteren om het werk beheersbaar te houden, zoals het ontmoedigen van cliënten om gebruik 
te maken van de diensten (Doornbos 2011). In ons onderzoek is hier geen sprake van. Wellicht heeft dit te maken met de speciale functie van het schadefonds als plus quam ultimum remedium (Groenhuijsen 2001, p. 931) voor slachtoffers van geweldscriminaliteit; zoals het strafrecht een laatste redmiddel is om daders van criminaliteit op het rechte pad te krijgen, zo is het schadefonds het allerlaatste redmiddel voor geweldsslachtoffers die hun schade niet op de dader kunnen verhalen en niet via een andere weg voor schadevergoeding in aanmerking komen. Om de legitimiteit van het schadefonds te waarborgen, is het van belang dat de beslissers van het schadefonds zich bewust zijn van deze functie en zo veel mogelijk beslissingen nemen die daar recht aan doen. Zowel de juristen van het secretariaat SGM als de leden van de commissie SGM die we hebben geïnterviewd, zijn zich terdege bewust van de solidariteitsfunctie van het schadefonds, hoewel zij lijken te verschillen in de manier waarop zij in de praktijk het beste recht kunnen doen aan deze functie. Aanvragers die een afwijzende beslissing hebben ontvangen, krijgen in bezwaar soms alsnog een uitkering toegekend, omdat commissieleden, meestal naar aanleiding van een hoorzitting, het gevoel hebben dat het niet onterecht zou zijn om hun het voordeel van de twijfel te gunnen. Volgens een van de geïnterviewde commissieleden past deze welwillendheid bij de solidariteitsfunctie van het schadefonds, terwijl de juristen van het secretariaat SGM het belangrijk zeggen te vinden om de solidariteitsfunctie ook in bezwaar te beperken tot aanvragers die op grond van de beleidsbundel recht hebben op een tegemoetkoming. Dit sluit aan bij het werk van Kagan (1978), die een onderscheid maakt tussen beslissers die meer aan de formele regels vasthouden en beslissers die meer georiënteerd zijn op de doelen van de organisatie.

Toekomstig onderzoek doet er goed aan om ook het theoretische perspectief van Kagan (1978) in de studie te betrekken. Daarnaast kan het inzicht in hoe de beslissers van het schadefonds omgaan met hun discretionaire bevoegdheid worden vergroot door andere onderzoeksmethoden te hanteren. Door onderzoek dat een experimenteel design heeft, kunnen bijvoorbeeld ook routines en heuristieken aan het licht komen waarvan de juristen van het secretariaat SGM en de leden van de commissie SGM zich niet bewust zijn.

\section{Referenties}

Ask, K., 'A survey of police officers' and prosecutors' beliefs about crime victim behaviors', Journal of Interpersonal Violence, 2010-25(6), p. 1132-1149.

Ask, K. \& S. Landström, 'Why emotions matter: Expectancy violation and affective response mediate the emotional victim effect', Law and Human Behavior 2010-34(5), p. 392-401.

Bosma, A.K., Emotive justice: Laypersons' and legal professionals' evaluations of emotional victims within the just world paradigm (diss.), Tilburg: Tilburg University 2019.

Bosma A.Q., M.J.J. Kunst, J.E. Dirkzwager \& P. Nieuwbeerta, 'Selection processes in prison-based treatment referrals: A street-level bureaucracy perspective', Crime \& Delinquency 2018-64(8), p. 1001-1032. 
Bottoms, B.L., S.L. Davis \& M.A. Epstein, 'Effects of victim and defendant race on jurors' decisions in child sexual abuse cases', Journal of Applied Social Psychology 2004- 34(1), p. 1-33.

Campbell, B.A., T.A. Menaker \& W.R. King, 'The determination of victim credibility by adult and juvenile sexual assault investigators', Journal of Criminal Justice 2015-43(1), p. 29-39.

Centraal Bureau voor Statistiek Veiligheidsmonitor 2016. Verkregen van www.cbs.nl/nl-nl/ publicatie/2017/09/veiligheidsmonitor-2016, 2017.

Clarke, A.K. \& L. Stermac, 'The influence of stereotypical beliefs, participant gender, and survivor weight on sexual assault response', Journal of interpersonal violence 2001-26(11), p. 2285-2302.

Christie, N., 'The ideal victim', in: E.A. Fattah (red.), From crime policy to victim policy, London, UK: Palgrave Macmillan 1986, p. 17-30.

Cozijn, C., Schadefonds geweldsmisdrijven, Den Haag: WODC 1984.

Decorte, T., 'Kwalitatieve data-analyse', in: T. Decorte \& D. Zaitch (red.), Kwalitatieve methoden en technieken in de Criminologie (derde herziene versie), Leuven/Den Haag: Acco 2016, p. 463-508.

Dekkers, T.J.M., Mobility, control, and technology in border areas. Discretion and decisionmaking in the information age (diss.), Leiden: Leiden University 2019.

Doornbos, N., 'Wat doen ambtenaren als ze regels toepassen?', in: M. Hertogh \& H. Weyers (red.), Recht van onderop: antwoorden uit de rechtssociologie, Nijmegen: Ars Aequi Libri 2011, p. 99-114.

Finucane, M.L., A. Alhakami, P. Slovic \& S.M. Johnson, The affect heuristic in judgments of risks and benefits, Journal of behavioral decision making 2000-13(1), p. 1-17.

Frohmann, L., Convictability and discordant locales: Reproducing race, class, and gender ideologies in prosecutorial decision-making, Law and Society Review 1997-31(3), p. 531-555.

Geenen, M.J., E. Kolthoff, R.C. van Halderen \& J. de Jong, 'Street-level bureaucrats in de justitiële jeugdinrichting?', Tijdschrift voor Criminologie 2016-58(4), p. 70-86.

Gigerenzer, G. \& W. Gaissmaier, Heuristic decision making, Annual Review of Psychology 2011-62(1), p. 451-482.

Groenhuijsen, M.S. (2001). Schadefondsen in Nederland en in het buitenland: Supra-nationale normen, rechtsvergelijkende en empirische beschouwingen. Delikt en Delinkwent, 31(11), 930-947.

Hine, B. \& A. Murphy, The impact of victim-perpetrator relationship, reputation and initial point of resistance on officers' responsibility and authenticity ratings towards hypothetical rape cases, Journal of Criminal Justice 2017-49(1), p. 1-13.

Kahneman, D. \& A. Tversky, 'Subjective probability: A judgment of representativeness', Cognitive Psychology 1972-3(3), p. 430-454.

Kolthoff, E., K. Loyens \& A. Verhage, 'Street-level bureaucracy en actoren in de veiligheidszorg', Tijdschrift voor Criminologie 2016-58(4), p. 3-9.

Kunst, M.J.J., 'Peritraumatic distress, posttraumatic stress disorder symptoms, and posttraumatic growth in victims of violence', Journal of Traumatic Stress 2010-23(4), p. 514-518.

Lerner, M.J., 'The desire for justice and reactions to victims', Altruism and helping behavior, 1970-205, p. 229-236.

Lerner, M.J., 'The desire for justice and reactions to victims: Social psychological studies of some antecedents and consequences', in: J. Macaulay \& L. Berkowitz (red.), Altruism andhelping behaviors, New York: Academic Press 1970, p. 205-229. 
Lerner, M.J., The belief in a just world: A fundamental delusion, New York: Plenum Press 1980.

Lerner, M.J. \& C.H. Simmons, 'Observer's reaction to the "innocent victim": Compassion or rejection?', Journal of Personality and social Psychology 1966-4(2), p. 203-210.

Lipsky, M., Street-level bureaucracy: Dilemmas of the individual in public services. New York: Russell Sage Foundation 1980.

Lipsky, M., Street-level bureaucracy: Dilemmas of the individual in public services (2nd ed.), New York: Russell Sage Foundation 2010.

Macmillan, R., 'Violence and the life course: The consequences of victimization for personal and social development', Annual review of sociology 2001-27(1), p. 1-22.

McCauley, M.R. \& J.F. Parker, 'When will a child be believed? The impact of the victim's age and juror's gender on children's credibility and verdict in a sexual-abuse case', Child Abuse \& Neglect 2001-25(4), p. 523-539.

Mueller-Johnson, K., M.P. Toglia, C.D. Sweeney \& S.J. Ceci, 'The perceived credibility of older adults as witnesses and its relation to ageism', Behavioral Sciences \& the Law 2007-25(3), p. 355-375.

Mulder, M.R. \& F.W. Winiel, 'Social workers' and police officers' perception of victim credibility: Perspective-taking and the impact of extra-evidential factors', Psychology, Crime and Law 1996-2(4), p. 307-319.

Nagle, J.E., S.L. Brodsky \& K. Weeter, 'Gender, smiling and witness credibility in actual trials', Behavioral Sciences and Law 2014-32(1), p. 195-206.

Raaphorst, N.J., Uncertainty in bureaucracy: Toward a sociological understanding of frontline decision making (diss. Rotterdam), Erasmus Universiteit Rotterdam 2017.

Schadefonds Geweldsmisdrijven, Bijlage beleidsbundel sinds 1 november 2017. Gevonden op: https://schadefonds.nl/nl/professionals/beleidsbundel-en-letsellijst 2017.

Sleath, E. \& R. Bull, 'Police perceptions of rape victims and the impact on case decision making: A systematic review', Aggression and Violent Behavior 2017-34(5), p. 102-112.

Vrij, A. \& H.R. Firmin, 'Beautiful thus innocent? The impact of defendants' and victims' physical attractiveness and participants' rape beliefs on impression formation in alleged rapecases', International Review of Victimology 2001-8(3), p. 245-255.

Wrede, O., The role of emotions in judgments of crime victims (diss.), Gothenburg University 2015.

Yamawaki, N., C. Riley, C. Rasmussen \& M. Cook, 'The effects of obesity myths on perceptions of sexual assault victims and perpetrators' credibility', Journal of interpersonal violence 2018-33(4), p. 662-685. 